Accepted: 09/10/2020, Reviewed: 04/11/2020, Published: 30/04/2021

\title{
EFFECT OF DEXTRIN CONCENTRATION AND DRYING TIME ON THE PHYSICAL, CHEMICAL AND ORGANOLEPTIC CHARACTERISTICS OF MUSHROOM BROTH POWDER
}

\author{
Dego Yusa Ali*, Bella Ayu Shafira, Yunianta \\ Department of Agricultural Product Technology, Faculty of Agricultural Technology, \\ Brawijaya University \\ JI. Veteran, Malang 65145 \\ ${ }^{*}$ Corresponding Author, Email: dego@ub.ac.id
}

\begin{abstract}
Several types of mushrooms such as white oyster mushrooms, shiitake and straw have a protein content with a high proportion of glutamic acid so that they can be utilized as broth powder. The purpose of this study was to determine the interaction of dextrin concentration and drying time and the best treatment on the physicochemical and organoleptic characteristics of mushroom broth powder. The study used the factorial Randomized Block Design (RBD) method, where the first factor was dextrin concentration $(7.50 \%, 12.50 \%$, $17.50 \%$ ) and the second factor was drying time (8 hours, 10 hours, 12 hours). The data were analyzed by using ANOVA and further tests used LSD or DMRT. The organoleptic test was carried out by using the Hedonic Scale Scoring test and the best treatment was chosen by using the Zeleny method. The results showed the addition of dextrin concentration and drying time gave significant interactions to the water content, water vapor absorption and yield. The best treatment was obtained in broth powder with a dextrin concentration of $7.50 \%$ and a drying time of 8 hours.
\end{abstract}

Keywords: Broth powder, Dextrin, Drying, Mushroom

\section{INTRODUCTION}

The use of food additives is very common in food products. One of the food additives that are often found is flavoring. Flavoring agents are divided into 2 groups, namely synthetic flavoring and natural flavoring (Mulyadi et al., 2013). The synthetic flavoring agent that has been widely distributed on the commercial market is monosodium glutamate (MSG). The addition of MSG to food products is useful for enhancing and emphasizing the taste and adding umami or savory flavors to food (Abdul-Hamid et al., 2017).

According to the Central Statistics Agency of Foreign Trade, MSG imports of Indonesia in 2016 reached 35,434,831 kg. Besides, in 2018 there was an increase in MSG imports to $40,731,795 \mathrm{~kg}$ (Central Statistics Agency, 2016; Central Statistics Agency, 2018). The increase in MSG imports shows that the use of MSG in Indonesia is relatively large and increases every year. The World Health Organization (WHO) through the Joint Expert Committee on Food Additives (1971) set a safe threshold for MSG for humans, namely 120 $\mathrm{mg} / \mathrm{kg}$ body weight per day. However, excessive use of MSG for a long period can cause health problems (Abdul-Hamid et al., 2017). Increasing public awareness of healthy lifestyles and foods has led people to start switching to food products that are considered safer for health. The development of flavoring products from natural glutamate sources is highly needed to substitute commercial flavorings on the market. One of the sources of natural glutamate that can be used is mushrooms.

Several types of mushrooms such as white oyster mushrooms, shiitake mushrooms and paddy straw mushrooms contain protein with a high proportion of glutamic acid. White oyster mushrooms have a glutamic acid content of $21.70 \mathrm{mg} / \mathrm{g}$ and shiitake mushrooms have a glutamic acid content of $26.00 \mathrm{mg} / \mathrm{g}$ (Widyastuti, Giarni, and Jokrokusumo, 2015). Paddy 
straw mushroom is known to contain glutamic acid of $14.59 \mathrm{mg} / \mathrm{g}$ (Eguchi et al., 2015). The high glutamic acid content resulted in these three types of mushrooms to be used as a flavoring for vegetable powder broth.

However, several factors must be considered in making the flavor of the broth, such as filler concentration and drying time. The addition of filler is used to accelerate the drying process and increase the yield of the final product. The filler used in the manufacture of mushroom powder broth is the dextrin. The use of filler concentration needs to be carefully considered since too high concentration will reduce the taste of food products; while too low concentration will result in low yields products and take longer time to dry (Hermansyah, Wignyanto, and Mulyadi, 2012).

In addition to the use of filler, the drying stage also needs to be considered since the accuracy of the drying time will affect the quality of the final product. The too long drying process will result in a too dry and dark color product. Meanwhile, a short drying time will result in a non-drying product with relatively high-water content. The purpose of this study was to determine the interaction of dextrin concentration and drying time and the best treatment on the physicochemical and organoleptic characteristics of mushroom broth powder.

\section{METHODOLOGY}

\section{Materials}

The materials used in the preparation of mushroom broth powder are fresh white oyster mushrooms obtained from a modern market in Malang. Packaged paddy straw mushroom under the name of Agro Mushroom Cemerlang brand consists of mushrooms and pure water. Dry shiitake mushroom under the brand of SU with the highest quality (A quality). Other supporting materials are salt (Cap Kapal), sugar (Gulaku), pepper (Ladaku), cooking oil (Cap Kuda), onions, shallots, and leeks obtained from Pasar Besar Malang. The filler in the form of white dextrin uses the Flower Brand with a DE value of $8.00-9.00 \%$.

The materials used for the test are Kjeldahl tablets (Merck), $\mathrm{H}_{2} \mathrm{SO}_{4}$ (Pro-analysis), 30\% $\mathrm{NaOH}, 4 \%$ boric acid, methyl red, indicators of $\mathrm{pp}, \mathrm{HCl} 32 \%$ distilled water $(\mathrm{pH} \pm 7)$, filter paper and aluminum foil obtained from a local company named Makmur Sejati.

\section{Tools}

The equipment used in this research includes a cabinet dryer (Local), 60 mesh sieve (Retsch), blender (Miyako BL-102GS), analytical scale (Mettler Toledo), digital scale (CHQ), $250 \mathrm{ml}$ erlenmeyer (Pyrex), $1000 \mathrm{ml}$ beaker glass(Pyrex), beaker glass $500 \mathrm{ml}$ (Pyrex, Scott Duran), $50 \mathrm{ml}$ measuring cup (Pyrex), $100 \mathrm{ml}$ measuring flask (Pyrex), oven (Memmert), digestion apparatus (Buchi), distillation apparatus (Buchi), kjeldahl flask (Buchi), desiccator (Nalgene), tongs, jars , glass spatula, $10 \mathrm{ml}$ measuring pipette (Pyrex), color reader (Minota CR10), dropper pipette, bulb (Vitlab), thermometer, cutting board, stove (Rinnai), baking sheet (Local), frying pan, pan, spoon, spatula, knife, filter cloth and basin.

\section{Research Design}

The research was conducted by using a Randomized Block Design (RBD) experimental design which was arranged in a factorial with 2 factors. The first factor was dextrin concentration $(7.50 \%, 12.50 \%, 17.50 \%)$ and the second factor was drying time (8 hours, 10 hours, 12 hours). In this study, 9 treatment combinations were repeated 3 times in order to obtain a total of 27 experiments.

Table 1. Analysis of Factorial RBD Data for Dextrin Concentration and Drying Time

\begin{tabular}{lllc} 
Dextrin & \multicolumn{3}{l}{ Drying Time (M) } \\
Concentration (L) & M1 (8 hours) & M2 (10 hours) & M3 (12 hours) \\
\hline L1 (7.50\%) & L1M1 & L1M2 & L1M3 \\
L2 (12.50\%) & L2M1 & L2M2 & L2M3 \\
L3 (17.50\%) & L3M1 & L3M2 & L3M3
\end{tabular}




\section{Research Stages}

The making of mushroom broth powder was based on preliminary research (Modification of Wulantiasari, 2019). The main ingredients, white oyster and paddy straw mushrooms, were washed under the running water. Dry shiitake mushrooms were then immersed in water $\left( \pm 28^{\circ} \mathrm{C}\right)$ for 15 minutes and then drained. The ingredients were white oyster mushrooms (150 grams), paddy straw mushroom (150 grams), shiitake mushrooms (150 grams), garlic ( $3 \%$ of the total weight of mushrooms) and shallots ( $2 \%$ of the total weight of mushrooms) were crushed with a blender at 1 speed for 1 minute and added with water (ratio of water : mushrooms $=2: 3)$. Slurry is then sauteed over low heat $\left(60 \pm 5^{\circ} \mathrm{C}\right)$ for 10 minutes. In the sauteing process, salt ( $3 \%$ of the total weight of mushrooms), sugar ( $2 \%$ of the total weight of mushrooms) and pepper (1\% of the total weight of mushrooms) were added. Furthermore, the boiling process with water (ratio of water: mushrooms $=2: 1$ ) was carried out at a temperature of $80 \pm 5^{\circ} \mathrm{C}$ for 30 minutes and leeks are added $(5 \%$ of the total weight of mushrooms).

After the boiling process, the mixture was then filtered using a filter cloth. The obtained broth filtrate was taken as much as $100 \mathrm{ml}$ and added with dextrins with a concentration of $7.50 \%, 12.50 \%, 17.50 \%(b / v)$. The broth was then poured into a baking sheet with a thickness of $0.20-0.30 \mathrm{~cm}$. The drying process of powder broth used a cabinet dryer at $60 \pm 3^{\circ} \mathrm{C}$ for 8 hours, 10 hours and 12 hours, respectively. The dried broth is mashed using a blender at the speed of 1 for 1 minute. The broth powder was then sieved in 60 mesh size.

\section{Methods}

The physical and chemical characteristics of mushroom broth powder were analyzed by using the ANOVA method with a 95\% confidence interval with the General Linear Model on the software of Minitab 17. The treatment with significant effect was then followed by the LSD test (smallest significant difference) or with the advanced test of DMRT ( Duncan Multiple Range Test ) to figure out if there is an interaction between the two treatments. The organoleptic test was performed by using the Hedonic Scale Scoring. The data was processed using the Friedman Test method using Minitab 17 software. The selection process of the best treatment based on physical, chemical and organoleptic characteristics was obtained by the Zeleny method using Microsoft Excel software.

\section{Analysis Procedure}

Physical analysis of mushroom broth powder including color measured by color reader (Yuwono and Susanto, 1998), yield (AOAC, 1995) and water vapor absorption (Yuwono and Susanto, 1998). Chemical analysis of mushroom broth powder included moisture content with oven method (AOAC, 1999) and protein content with Kjeldahl method (AOAC, 1999).

\section{Sensory Analysis}

The sensory analysis used Hedonic Scale Scoring with sensory attributes in the form of color, appearance, aroma, taste and overall liking. The hedonic test was carried out by 100 untrained panelists from the students of the Faculty of Agricultural Technology, Brawijaya University. Before serving, the broth is dissolved in water at $60^{\circ} \mathrm{C}$ with a proportion of 2 grams of mushroom broth powder in $50 \mathrm{ml}$ of water (Ramadhani, 2015). The hedonic test in the research used 7 levels of the liking scale, namely very like, like, somewhat like, neutral, somewhat dislike, dislike and very dislike (Granato, Masson, and Ribeiro, 2012)

\section{RESULTS AND DISCUSSION}

\section{Water Content of Mushroom Broth Powder}

The increase in the water content of powder products is characterized by clumping and hardness. Based on the research, it is known that the analysis results of the water content of mushroom broth powder ranged from $4.86-6.86 \%$. 
Table 2. Average Physical and Chemical Characteristics at Different Dextrin Concentration and Drying Time

\begin{tabular}{|c|c|c|c|c|}
\hline \multicolumn{2}{|c|}{ Treatment } & \multirow[b]{2}{*}{$\begin{array}{l}\text { Average Water } \\
\text { Content (\%) }\end{array}$} & \multirow[b]{2}{*}{$\begin{array}{c}\text { Average Yield } \\
(\%)\end{array}$} & \multirow[b]{2}{*}{$\begin{array}{c}\text { Average Water } \\
\text { Vapor Absorption } \\
(\%)\end{array}$} \\
\hline $\begin{array}{c}\text { Dextrin } \\
\text { Concentratio } \\
\mathrm{n}(\%)\end{array}$ & $\begin{array}{l}\text { Drying } \\
\text { Time } \\
\text { (hours) }\end{array}$ & & & \\
\hline 7.50 & 8 & $6.86 \pm 0.14^{a}$ & $10.21 \pm 0.54^{f}$ & $17.89 \pm 0.56^{f}$ \\
\hline 7.50 & 10 & $6.25 \pm 0.12^{b}$ & $9.45 \pm 0.35^{\mathrm{g}}$ & $18.57 \pm 0.11^{\text {ef }}$ \\
\hline 7.50 & 12 & $5.87 \pm 0.10^{c d}$ & $9.13 \pm 0.25^{g}$ & $19.22 \pm 0.20^{\mathrm{de}}$ \\
\hline 12.50 & 8 & $6.05 \pm 0.12^{b c}$ & $13.42 \pm 0.29^{d}$ & $19.39 \pm 0.39^{d e}$ \\
\hline 12.50 & 10 & $5.81 \pm 0.11^{d}$ & $13.03 \pm 0.36^{\mathrm{de}}$ & $19.78 \pm 0.19^{d}$ \\
\hline 12.50 & 12 & $5.52 \pm 0.13^{e}$ & $12.49 \pm 0.28^{e}$ & $21.27 \pm 0.70^{c}$ \\
\hline 17.50 & 8 & $5.74 \pm 0.21^{d}$ & $17.19 \pm 0.46^{a}$ & $21.02 \pm 0.86^{c}$ \\
\hline 17.50 & 10 & $5.42 \pm 0.11^{e}$ & $15.85 \pm 0.26^{b}$ & $22.67 \pm 0.43^{b}$ \\
\hline 17.50 & 12 & $4.86 \pm 0.09^{f}$ & $14.81 \pm 0.41^{c}$ & $24.86 \pm 0.49^{a}$ \\
\hline
\end{tabular}

Description:

1) Each data is the average of 3 repetitions \pm standard deviation

2) The number along with the different notations indicates significant differences in the DMRT advanced test $(\alpha=0.05)$

Table 2 shows that the lowest water content was obtained at $17.50 \%$ dextrin concentration and 12 hours of drying time. The drying time was influenced by the high concentration of dextrin in mushroom broth. The higher the total solids in the liquid broth, the lower the amount of water content in the liquid broth. Compared with the research of Abidin, Yuwono, and Maligan (2019), the addition of fillers in the form of maltodextrin produces mushroom broth that dries faster and has lower water content. The increase of dextrin concentration causes the water content to decrease due to the increase in total solids (Firdhausi et al., 2015). The longer the drying time, the longer the material's contact with heat and the greater the evaporation of water (Erni, Kadirman, and Fadilah, 2018).

\section{Yield of Mushroom Broth Powder}

The yield is the percentage ratio of the final weight of the product produced by the weight of the material before processing. Table 2 shows that the highest yield was obtained at $17.50 \%$ dextrin concentration and 8 hours of drying time. The higher the dextrin concentration and the shorter the drying time causes the increasing yield of the mushroom broth.

Compared with the research of Abidin, Yuwono, and Maligan (2019), in the production of white oyster mushroom broth powder, the addition of the concentration of maltodextrin and egg white increases the yield of the final product. The yield increase was directly proportional to the dextrin concentration due to the rise in total solids. Drying time also affects the yield produced where the longer the drying process, the lower the yield tends to be. This is because the drying process will cause more free water components to be evaporated, which then results in a shrinkage of product weight.

\section{Water Vapor Absorption of Mushroom Broth Powder}

Table 2 shows that the highest water vapor absorption was obtained at $17.50 \%$ dextrin treatment and 12 hours of drying time. The higher the dextrin concentration and the drying time, the higher the water vapor absorption value of mushroom broth powder. Compared with the research of Firdhausi et al. (2015), the addition of dextrin and gum arabic in instant shrimp head paste will reduce water content. Therefore, it has a high tendency to absorb water in the environment.

The absorption of water vapor is related to the moisture content in a product where the product which has a low water content has a higher ability to absorb water vapor. The concentration of dextrin is also directly proportional to the hydroxyl group so that its hygroscopic ability increases with the increase in filler concentration (Firdhausi et al., 2015). 
The drying time also affects the absorption of water vapor produced, where the longer it dries, the greater the evaporated water is. The drying process causes the product to have more hygroscopic characteristics than non-dried materials. This causes products with low water content to tend to absorb water until it reaches a balance condition (Sari and Kusnadi, 2015).

\section{Protein Content of Mushroom Broth Powder}

The protein content analysis was carried out to find out the protein content in the broth powder where the mushroom, as the raw material used, was known to have a high protein content.

Table 3. Average Physical and Chemical Characteristics at Different Dextrin Concentrations

\section{Treatment}

\begin{tabular}{ccccc}
\hline $\begin{array}{c}\text { Dextrin } \\
\text { Concentration } \\
(\%)\end{array}$ & $\begin{array}{c}\text { Average Protein } \\
\text { Content (\%) }\end{array}$ & L Value* $^{*}$ & a Value* $^{*}$ & b Value* $^{*}$ \\
\hline 7.50 & $3.61 \pm 0.25^{\mathrm{a}}$ & $77.35 \pm 0.30^{\mathrm{c}}$ & $2.19 \pm 0.95^{\mathrm{a}}$ & $21.69 \pm 0.36^{\mathrm{a}}$ \\
12.50 & $3.03 \pm 0.24^{\mathrm{b}}$ & $81.08 \pm 1.20^{\mathrm{b}}$ & $1.26 \pm 0.71^{\mathrm{b}}$ & $18.82 \pm 1.62^{\mathrm{b}}$ \\
17.50 & $2.33 \pm 0.25^{\mathrm{c}}$ & $83.15 \pm 0.93^{\mathrm{a}}$ & $0.80 \pm 0.58^{\mathrm{c}}$ & $16.18 \pm 0.58^{\mathrm{c}}$ \\
\hline
\end{tabular}

Description:

1) Each data is the average of 3 repetitions \pm standard deviation

2) The number along with the different notations indicates significant differences in the BNT advanced test $(\alpha=0.05)$

Table 4. Average Physical and Chemical Characteristics at Different Drying Time

\begin{tabular}{ccccc}
\hline $\begin{array}{c}\text { Treatment } \\
\begin{array}{c}\text { Drying Time } \\
\text { (hours) }\end{array}\end{array}$ & $\begin{array}{c}\text { Average } \\
\text { Protein } \\
\text { Content (\%) }\end{array}$ & L Value $^{*}$ & a Value $^{*}$ & b Value $^{*}$ \\
\hline 8 & $3.22 \pm 0.65^{\mathrm{a}}$ & $81.32 \pm 2.72^{\mathrm{a}}$ & $2.19 \pm 0.91^{\mathrm{a}}$ & $19.73 \pm 2.97^{\mathrm{a}}$ \\
10 & $3.03 \pm 0.62^{\mathrm{b}}$ & $80.56 \pm 2.92^{\mathrm{b}}$ & $1.33 \pm 0.68^{\mathrm{b}}$ & $18.93 \pm 2.70^{\mathrm{a}}$ \\
12 & $2.73 \pm 0.65^{\mathrm{c}}$ & $79.71 \pm 3.23^{\mathrm{c}}$ & $0.72 \pm 0.55^{\mathrm{c}}$ & $18.03 \pm 2.75^{\mathrm{b}}$ \\
\hline
\end{tabular}

Description:

1) Each data is the average of 3 repetitions \pm standard deviation

2) The number along with the different notations indicates significant differences in the BNT advanced test $(\alpha=0.05)$

Table 3 shows that the higher the addition of dextrin concentration decreased the protein content in the mushroom broth powder. This is in line with the literature where the addition of filler concentrations will decrease protein levels. This occurs since dextrins are a carbohydrate group and do not contain protein components. This causes low protein content due to the increase in carbohydrate content (Firdhausi et al., 2015).

Table 4 shows that the longer the drying time, the lower the protein content in the mushroom broth powder. Crude protein measurement analysis is based on nitrogen content in food products. The heating process can cause the protein to denature, resulting in changes to the protein structure (Estiasih et al., 2016). The protein denaturation process does not affect the nitrogen content in the broth so there was a discrepancy with the literature.

\section{5. $\quad$ Lightness Value ( $L$ *)}

Table 3 shows that the higher the addition of dextrin concentration increased the $L^{*}$ value in the mushroom broth powder. The resulting product has brighter color as dextrins are white. This is in line with the literature where the addition of dextrin concentrations in red guava juice powder produces a product with a brighter color (Suryanto, 2018).

Table 4 shows that the longer the drying time, the lower the $L^{*}$ value in the mushroom broth powder. This is consistent with the literature where the presence of high temperatures and long drying times causes a non-enzymatic browning reaction called the Maillard reaction. The Maillard reaction is a reaction between reducing sugar groups (dextrins) and amino acids 
(mushrooms), resulting in a brownish color. The longer foodstuffs are exposed to hot temperatures, its surface will change color to brown (Shabrina and Susanto, 2017).

\section{Redness Value $\left(a^{*}\right)$}

Measurement of the reddish value $\left(a^{*}\right)$ and the yellowish value $\left(b^{*}\right)$ needs to be conducted since the drying process causes the color of the product to turn brown. Table 3 shows that the higher the addition of dextrin concentration causes the $a^{*}$ value in the mushroom broth powder to decrease. In a study conducted by Yuliwaty and Susanto (2015), the addition of a filler in the form of maltodextrin causes the redness level to decrease in instant drink noni leaves due to the white effect of maltodextrin. This shows that the color of the type of filler used will affect the color of the product and cause the intensity of the red color to decrease.

Table 4 shows that the longer drying time causes the $a^{*}$ value in the mushroom broth powder to decrease. The decrease of redness level presumably due to the long drying time which causing the material to have greater contact with the heat. This is because the long drying time causes Maillard reaction as well as changes in the color pigments in the product (Shabrina and Susanto, 2017).

\section{Yellowness Value ( $\left.\mathbf{b}^{*}\right)$}

Table 3 shows that the higher the addition of dextrin concentration causes the value of $b^{*}$ in mushroom broth powder to decrease. The decrease in yellowish color is due to the use of dextrin which has a white base color so that it will reduce the intensity of the yellowish color in the broth.

Table 4 shows that the longer drying time causes the $b^{*}$ value in the mushroom broth powder to decrease. This decrease was caused by the browning process which caused the yellow pigment in the product to turn brown and suffer damage. In fungi, there are pigment components such as flavonoids and carotenoids. Bioactive components such as flavonoids will experience damage at temperatures of $50^{\circ} \mathrm{C}$ (Yuliantari, Widarta, and Permana, 2017).

\section{Organoleptic Analysis}

Table 5 shows that the broth that has the highest total preference ranking in color parameters is the dextrin concentration treatment of $7.50 \%$ with a drying time of 12 hours. The treatment with a dextrin concentration of $17.50 \%$ and drying time of 10 hours had the color most disliked by the panelists. This because it was cloudy white and did not resemble the familiar broth color characteristics. Compared with the research of Naibaho et al., (2015), the color of instant shrimp paste products most favored by panelists was at $5 \%$ dextrin concentration while $15 \%$ concentration was the least preferred color. The cloudy white color is because dextrins are white. The more dextrin concentration is added, the resulting broth will be pale white and far from the broth color criteria.

Table 5. Average Favorability Level of Organoleptic Attributes of Mushroom Broth

\begin{tabular}{|c|c|c|c|c|c|c|}
\hline \multicolumn{2}{|c|}{ Treatment } & \multirow[b]{2}{*}{$\begin{array}{r}\text { Color } \\
\text { Attribute }\end{array}$} & \multirow[b]{2}{*}{$\begin{array}{l}\text { Appearance } \\
\text { Attribute }\end{array}$} & \multirow[b]{2}{*}{$\begin{array}{c}\text { Aroma } \\
\text { Attribute }\end{array}$} & \multirow[b]{2}{*}{$\begin{array}{c}\text { Taste/Flavor } \\
\text { Attribute }\end{array}$} & \multirow[b]{2}{*}{$\begin{array}{l}\text { Attribute of } \\
\text { Overall Liking }\end{array}$} \\
\hline $\begin{array}{c}\text { Dextrin } \\
\text { Concentratio } \\
n(\%)\end{array}$ & $\begin{array}{l}\text { Drying } \\
\text { Time } \\
\text { (hours) }\end{array}$ & & & & & \\
\hline 7.50 & 8 & $4.46 \pm 1.34$ & $4.67 \pm 1.46$ & $4.33 \pm 1.32$ & $4.72 \pm 1.48$ & $4.64 \pm 1.24$ \\
\hline 7.50 & 10 & $4.04 \pm 1.25$ & $4.56 \pm 1.29$ & $4.35 \pm 1.55$ & $4.59 \pm 1.41$ & $4.46 \pm 1.28$ \\
\hline 7.50 & 12 & $4.67 \pm 1.18$ & $4.97 \pm 1.09$ & $4.51 \pm 1.23$ & $4.74 \pm 1.40$ & $4.75 \pm 1.26$ \\
\hline 12.50 & 8 & $4.37 \pm 1.36$ & $4.55 \pm 1.50$ & $4.49 \pm 1.63$ & $3.96 \pm 1.37$ & $4.31 \pm 1.35$ \\
\hline 12.50 & 10 & $4.51 \pm 1.26$ & $4.58 \pm 1.29$ & $4.14 \pm 1.21$ & $4.14 \pm 1.36$ & $4.27 \pm 1.15$ \\
\hline 12.50 & 12 & $4.49 \pm 1.24$ & $4.53 \pm 1.09$ & $4.09 \pm 1.22$ & $4.53 \pm 1.09$ & $4.26 \pm 1.15$ \\
\hline 17.50 & 8 & $4.24 \pm 1.30$ & $4.38 \pm 1.33$ & $3.95 \pm 1.17$ & $3.63 \pm 1.43$ & $3.98 \pm 1.23$ \\
\hline 17.50 & 10 & $4.51 \pm 1.24$ & $4.19 \pm 1.26$ & $4.11 \pm 1.22$ & $3.67 \pm 1.48$ & $4.14 \pm 1.26$ \\
\hline 17.50 & 12 & $4.55 \pm 1.31$ & $4.63 \pm 1.27$ & $3.90 \pm 1.33$ & $3.50 \pm 1.44$ & $3.97 \pm 1.22$ \\
\hline
\end{tabular}


Based on the appearance parameter, the broth that has the highest total preference ranking is in the dextrin concentration treatment of $7.50 \%$ with a drying time of 12 hours because it has a dark overall appearance. At a concentration of $7.50 \%$ with a drying time of 8 hours, a bright overall visual appearance was obtained. The treatment with a dextrin concentration of $7.50 \%$ and a drying time of 10 hours produced the least favorable appearance. This is because it had an overall visual appearance which did not produce the expected colors (it should be less bright and there was sediment). Sediment can be formed as a result of a drying process that uses high temperatures with a short drying time which causes only the surface to dry, while the inside does not dry optimally (Naibaho et al., 2015).

Based on aroma parameters, the broth that has the highest total preference ranking is in the dextrin concentration treatment of $7.50 \%$ with a drying time of 12 hours. The addition of dextrin in the right amount will be able to protect compounds that are sensitive to oxidation or heat. Therefore, although the drying process is carried out for a long time (12 hours), the aroma and flavor will remain stable. The treatment with $17.50 \%$ dextrin concentration and 12 hours of drying time produced the aroma that was least liked by the panelists because it had a less strong aroma. The use of dextrins with high concentrations is expected to not only bind flavors but cause the formation of multilayer walls, so that the core material, namely aroma, was trapped (Gibbs et al., 1999).

Based on the parameters of taste, it is known that the broth that has the highest total preference ranking is in the dextrin concentration treatment of $7.50 \%$ with a drying time of 12 hours. The treatment with $17.50 \%$ dextrin concentration and 12 hours of drying time resulted in a taste that was not liked by the panelists because it had a taste like flour and was not savory. According to Ekafitri, Surahman, and Afifah (2016), the addition of dextrin with too high concentration can decrease the panelists' preference for taste parameters because dextrins can reduce the taste of food products. The drying time will also affect the taste of the broth due to heat-damaged compounds.

Based on the parameter of the overall liking, it is known that the broth with the highest total preference ranking is in the dextrin concentration treatment of $7.50 \%$ with a drying time of 12 hours. Panelists prefer this treatment because it has a dark brownish yellow color, savory taste, strong mushroom aroma, little sedimentation appears and a less cloudy appearance. Treatment with dextrin concentration of $17.50 \%$ and drying time of 12 hours resulted in overall liking which was the least preferred, because it had sediment, starchy taste, was not savory, had a cloudy white appearance and had a weak aroma. The use of too high a concentration is thought to cover the taste of the mushroom broth and can bind the flavor components excessively, thereby reducing the sensory properties (Gibbs et al., 1999).

\section{The Best Treatment}

The best treatment is determined by providing an ideal value on the tested parameters based on Multiple Criteria Decision Making(Zeleny, 1982). In these tests, all parameters are considered crucial. The determination of the best treatment was seen from all physical, chemical and organoleptic parameters. Based on the Zeleny method, the best treatment was obtained in mushroom broth powder with a concentration of $7.50 \%$ dextrin and 8 hours of drying time. The best treatment has physical, chemical and organoleptic characteristics as in Table 6. 
Table 6. Physical, Chemical, and Organoleptic Characteristics of Best Treatment

\begin{tabular}{lc}
\hline Parameter & Result \\
\hline Water Content $(\%)$ & $6.86 \pm 0.14$ \\
Protein Content $(\%)$ & $3.86 \pm 0.14$ \\
Yield (\%) & $10.21 \pm 0.54$ \\
Water vapor absorption (\%) & $17.89 \pm 0.56$ \\
Color & \\
Color Lightness $\left(\mathrm{L}^{*}\right)$ & $78.26 \pm 0.42$ \\
Redness $\left(\mathrm{a}^{*}\right)$ & $3.21 \pm 0.22$ \\
Yellowness $\left(\mathrm{b}^{\star}\right)$ & $21.31 \pm 0.26$ \\
Color Parameters Hedonic & $4.67 \pm 1.46$ \\
Hedonic Appearance Parameters & $4.46 \pm 1.34$ \\
Aroma Parameters Hedonic & $4.33 \pm 1.32$ \\
Flavor Parameters Hedonic & $4.72 \pm 1.48$ \\
Parameter Hedonic of Overall Liking & $4.64 \pm 1.24$ \\
\hline
\end{tabular}

\section{CONCLUSIONS}

The interaction between dextrin concentration and drying time had a significant effect $(\alpha=0.05)$ on water content, water vapor absorption and yield. The best treatment based on physical, chemical and organoleptic characteristics was obtained in mushroom broth powder with a dextrin concentration of $7.50 \%$ and drying time of 8 hours. The characteristics of the resulting product including water content of $6.86 \%$; protein content of $3.86 \%$, yield $10.21 \%$, water vapor absorption $17.89 \%$, value of $L^{*} 78.26$, value of $a^{*} 3.21$, value of $b^{*} 21.31$, and organoleptic in the form of color 4.67 , aroma 4.33 , taste 4.72 , appearance 4.46 and overall liking 4.64.

\section{REFERENCES}

Abdul-Hamid, M., Galaly, S. R., Ahmed, R. R., \& Hamdalla, H. M. (2017). Monosodium Glutamate as a Food Additive: Toxic Implications and the Protective Role of Quercetin. Merit Research Journal of Medicine and Medical Sciences, 5(8), 384-402.

Abidin, A. F., Yuwono, S. S., \& Maligan, J. M. (2019). Pengaruh Penambahan Maltodekstrin dan Putih Telur Terhadap Karakteristik Bubuk Kaldu Jamur Tiram. Jurnal Pangan Dan Agroindustri, 7(4), 53-61. https://doi.org/10.21776/ub.jpa.2019.007.04.6

Association of Official Analytical Chemists (AOAC). (1995). Official Methods of Analysis of AOAC International (16th editi; Patricia Cunniff, Ed.). Washington, D.C.: Association of Official Analytical Chemists.

Association of Official Analytical Chemists (AOAC). (1999). Official Methods of Analysis of AOAC International (P Cunniff, Ed.). Washington, D.C.: Association of Official Analytical Chemists.

Badan Pusat Statistik. (2016). Buletin Statistik Perdagangan Luar Negeri Impor Desember 2016. Retrieved July 10, 2020, from https://www.bps.go.id/publication/2017/02/27/98634968aaefcf75bc3e279d/buletinstatistik-perdagangan-luar-negeri-impor-desember-2016.html

Badan Pusat Statistik. (2018). Buletin Statistik Perdagangan Luar Negeri Impor Desember 2018. Retrieved July 10, 2020, from https://www.bps.go.id/publication/download.html?nrbvfeve=ZWEzNDZINTQzMThjYzk wZjFkZjQ4YzY1\&xzmn=aHR0cHM6Ly93d3cuYnBzLmdvLmlkL3B1YmxpY2F0aW9uLz IwMTkvMDMvMDgvZWEzNDZINTQzMThjYzkwZjFkZjQ4YzY1L2J1bGV0aW4tc3RhdG IzdGIrLXBIcmRhZ2FuZ2FuLWx1YXItbmVnZXJpLWItcG9yLWRIc2VtYmVyLTIwMTgua HRtbA\%3D\%3D\&twoadfnoarfeauf=MjAyMC0xMS0yMyAxMzowMToxMQ\%3D\%3D

Eguchi, F., Kalaw, S. P., Dulay, R. M. R., Miyasawa, N., Yoshimoto, H., Seyama, T., \& Reyes, R. G. (2015). Nutrient Composition and Functional Activity of Different Stages in the 
Fruiting Body Development of Philippine Paddy Straw Mushroom, Volvariella volvacea (Bull.:Fr.) Sing. Advances in Environmental Biology, 9(22), 54-65.

Ekafitri, R., Surahman, D. D., \& Afifah, N. (2016). Pengaruh Penambahan Dekstrin dan Albumen Telur (Putih Telur) Terhadap Mutu Tepung Pisang Matang. Jurnal Litbang Industri, 6(1), 13-24. https://doi.org/10.24960/jli.v6i1.1062.13-24

Erni, N., Kadirman, K., \& Fadilah, R. (2018). Pengaruh Suhu dan Lama Pengeringan terhadap Sifat Kimia dan Organoleptik Tepung Umbi Talas (Colocasia esculenta). Jurnal Pendidikan Teknologi Pertanian, 4(1), 95-105. https://doi.org/10.26858/jptp.v1i1.6223

Estiasih, T., Harijono, Waziiroh, E., \& Febrianto, K. (2016). Kimia dan Fisik Pangan. Jakarta: Bumi Aksara.

Firdhausi, C., Kusnadi, J., \& Ningtyas, D. W. (2015). Penambahan Dekstrin dan Gum Arab Petis Instan Kepala Udang terhadap Sifat Fisik, Kimia dan Organoleptik. Jurnal Pangan Dan Agroindustri, 3(3), 972-983.

Gibbs, B. F., Kermasha, S., \& Inteaz, A. (1999). Encapsulation in The Food Industry: A Review. International Journal of Food Sciences and Nutrition, 50(3), 213-224. https://doi.org/10.1080/096374899101256

Granato, D., Masson, M. L., \& Ribeiro, J. C. B. (2012). Sensory Acceptability and Physical Stability Evaluation of A Prebiotic Soy-based Dessert Developed with Passion Fruit Juice. Food Science and Technology, 32(1), 119-126. https://doi.org/10.1590/S010120612012005000004

Hermansyah, R., Wignyanto, \& Mulyadi, A. F. (2012). Pembuatan Tepung Pewarna Alami dari Limbah Pengolahan Daging Rujungan (Kajian Konsentrasi Dekstrin, Suhu Pengeringan dan Analisis Biaya Produksi). Jurnal Industria, 1(1), 40-49.

Mulyadi, A. F., Maligan, J. M., Wignyanto, \& Hermansyah, R. (2013). Karakteristik Organoleptik Serbuk Perisa Alami dari Cangkang Rajungan (Portunus pelagicus) Kajian Konsentrasi Dekstrin dan Suhu Pengeringan. Jurnal Teknologi Pertanian, 14(3), 183192.

Naibaho, L. T., Suhaidi, I., \& Ginting, S. (2015). Pengaruh Suhu Pengeringan dan Konsentrasi Dekstrin terhadap Mutu Minuman Instan Bit Merah. J.Rekayasa Pangan Dan Pert., 3(2), 178-184.

Ramadhani, A. R. (2015). Karakteristik Organoleptik Bubuk Flavor Kepala Ikan Tengiri dengan Bahan Pengisi Tepung Terigu. Universitas Padjadjaran.

Sari, V. R., \& Kusnadi, J. (2015). Pembuatan Petis Instan (Kajian Jenis dan Proporsi Bahan Pengisi). Jurnal Pangan Dan Agroindustri, 3(2), 381-389.

Shabrina, Z. U., \& Susanto, W. H. (2017). Pengaruh Suhu dan Lama Pengeringan dengan Metode Cabinet Dryer terhadap Karakteristik Manisan Kering Apel Varietas Anna (Malus domestica Borkh). Jurnal Pangan Dan Agroindustri, 5(3), 60-71.

Suryanto, R. (2018). Pengaruh Penambahan Dekstrin Dan Tween 80 Terhadap Sifat Fisik, Kimia Dan Organoleptik Bubuk Sari Buah Jambu Biji Merah (Psidium Guajava L.) Yang Dibuat Dengan Metode Foam-Mat Drying. Jurnal IImu Sosial Dan Pendidikan, 2(3), 7179. https://doi.org/10.36312/jisip.v2i3.495

WHO. (1971). Evaluation of Food Addictives: Specifications for The Identity and Purity of Food Additives and Their Toxicological Evaluation, Some Extraction Solvents and Certain Other substances. Retrieved from https://apps.who.int/iris/bitstream/handle/10665/40848/WHO_TRS_462.pdf?sequence $=1 \&$ isAllowed $=\mathrm{y}$.

Widyastuti, N., Giarni, R., \& Jokrokusumo, D. (2015). Potensi Beberapa Jamur Basidiomycota Sebagai Bumbu Penyedap Alternatif Masa Depan. Prosiding Seminar Agroindustri Dan Lokakarya Nasional FKPT-TPI, 52-60. Surabaya: Universitas Trunojoyo Madura.

Wulantiasari, W. (2019). Pengaruh Suhu dan Lama Pengeringan Terhadap Sifat Fisikokimia Pada Perisa Bubuk Kaldu Jamur Tiram Putih. Universitas Brawijaya.

Yuliantari, N. W. A., Widarta, I. W. R., \& Permana, I. D. G. M. (2017). Pengaruh Suhu dan Waktu Ekstraksi Terhadap Kandungan Flavonoid dan Aktivitas Antioksidan Daun Sirsak (Annona muricata L.) Menggunakan Ultrasonik. Media IImiah Teknologi Pangan, 4(1), 35-42. 
Yuliwaty, S. T., \& Susanto, W. H. (2015). Pengaruh Lama Pengeringan dan Konsentrasi Maltodekstrin terhadap Karakteristik Fisik Kimia dan Organoleptik Minuman Instan daun Mengkudu (Morinda citrifolia L.). Jurnal Pangan Dan Agroindustri, 3(1), 41-52.

Yuwono, S., \& Susanto, T. (1998). Pengujian Fisik Pangan. Malang: Fakultas Teknologi Pertanian, Universitas Brawijaya.

Zeleny, M. (1982). Multiple Criteria Decision Making (McGraw-Hill Series in Quantitative Methods for Management). New York: McGraw-Hill. 